\title{
Legal Principles Under Criminal Law in Indonesia Dan Thailand
}

\author{
Anirut Chuasanga ${ }^{1}$ and Ong Argo Victoria ${ }^{2}$
}

Abstract. The principle of legality is known in modern criminal law emerge from the scope of sociological Enlightenment doctrine that exalts the protection of people from abuse of power. Before coming Age of Enlightenment, the power to punish even without any regulations first. At that time, tastes kekuasaanlah most right to determine whether an act to be punished or not. To combat that, exists the principle of legality which is an important instrument of the protection of individual liberties in the face of the country. Thus, what is called the action that can be put into a regulatory authority, not power. According to legal experts, the roots of the idea of the principle of legality is derived from the provisions of Article 39 of the Magna Carta (1215) in the United Kingdom which ensure the protection of people from arrest, detention, seizure, disposal, and release of a person from the protection of the law / legislation, unless there is a judicial decision legitimate. This provision is followed Habeas Corpus Act (1679) in the UK that requires someone who is arrested is checked in a short time. This idea inspired the emergence of one of the provisions in the Declaration of Independence (1776) in the United States that says, no one should be prosecuted or arrested in addition to, and because of the actions set out in, legislation.

Keywords: Principle of Legality; Criminal law; Indonesia; Thailand.

\section{Introduction}

Indonesian law state explicitly conceived as a legal state that is prismatic, combining the positive aspects of rechtstaat with legal certainty and the rule of law with a sense of justice in an integrative, not only rechtstaat and not just the rule of law. Article 1 (3) of the 1945 results of the changes mentioned that Indonesia is "state law" point, without a word rechtstaat placed in parentheses. It must be understood that Indonesian law states accepted the principle of legal certainty, that the emphasis on rechtstaat, while accepting the principle of fairness, the emphasis on the rule of law. Such understanding is affirmed also in Article 28H 1945 also emphasized the importance of expediency and fairness, whereas Article 28D stressed the importance of legal certainty. ${ }^{3}$

Enforcement Principle of Legality aims to protect human rights, for human rights is the most essential rights, which should not be reduced at all. One of the provisions of the legality principle is to prohibit the enactment of legislation to retroactively (retroactive). But in reality people are always progressing, and the law always follow the development of the community. In such context, the law should not always be left

\footnotetext{
${ }^{1}$ Fatoni University, Thailand, Email: anirut2458@gmail.com

${ }^{2}$ International Islamic University Malaysia, Email: argovictoriaupin@gmail.com

3 Moh Mahfud MD, dalam Tjandra Sridjaja Pradjonggo, Sifat Melawan Hukum Dalam Tindak Pidana Korupsi, Indonesia Lawyer Club, Surabaya, Second Printing 2010, p.ix.
} 
behind with the development of society. Then one of the paradigm shift that has been achieved is by imposing a retroactive principle (retroactive) which significantly deviate the principle of legality in order to protect human rights, as well as the achievement of a sense of justice. Imposition of retroactive principle in Indonesia are limited, applied to the crime of serious human rights violations or crimes of cruelty and destructs level equal. Indonesia adheres to the principle of legality contained in Article 1 (1) of the Criminal Code that states not an act can be imprisoned except by the force of the criminal rules in the legislation that existed before the deed is done. The principle is this a reference for application of the rules at the same time the protection of human rights in Indonesia.

\section{Discussion}

\subsection{Basic Principles of State Law}

In the perspective of a state of law, the principle of delictum crimen nulla poena sine praevia lege poenali ${ }^{4}$ or the principle of legality is a matter that can not be circumvented, but historically explained that the growth and development of the principle of legality or the Principle of Legality as fundamental principles of the criminal law in most of the criminal justice system appears on the Enlightenment or the Age of Aufklarung, the 15th Century that dominated by the view of realism. It is not independent of the influence of changes in the political thought and philosophy of law that developed in mainland Europe. Applicability of the principle of legality provide protection to the nature of society. Criminal law provides a concession to protect the people of the implementation of the unlimited power of government or state power. There is no criminal prosecution except on the basis of the law, this is a function of protecting the principle of legality. In addition to these functions, the principle of legality also have an instrumental function. In the second function, at the limits of the corridor defined by law, the implementation of criminal law enforcement powers expressly justified. In other words, can be perceived as instrumental function"no criminal acts were not prosecuted",

Greeting delictum crimen nulla poena sine praevia lege poenalli came from Anselm von Feuerbach, German criminal law scholar (1775-1833). It was he who defined it in the Latin maxim earlier in his book:"Lehrbuch des peinlichen Recht"(1801). In relation to the function of the principle of legality that is giving protection to the criminal law, and the instrumental function, the term is divided into three, namely:

- Nulla poena sine lege: no crime without a criminal provision under the law;

- Nulla poena sine crimine: no punishment without a crime;

- Crimen crimen sine poena legalli: No crime without punishment according to law. ${ }^{5}$ Between the years 1775-1833, Anselm von Feuerbach, with respect to both functions formulate the principle of legality steadily in Latin as already mentioned above, that

\footnotetext{
${ }^{4}$ Terminology "the principle of nulla poena" is used by the PAF Lamintang to explain the meaning contained in the provisions of Article 1 (1) of the Criminal Code (see PAF Lamintang, Fundamentals of Criminal Law, Citra Aditya Bakti, Bandung, 1997, p.130.)

${ }^{5}$ Bambang Poernomo, Asas-asas Hukum Pidana, Ghalia Indonesia, Jakarta, 1994, p.68
} 
principle means that there is no crime, no punishment without law power first. The motto of the then popular in the Criminal Code states with the Continental European system or the civil law that embraces the concept of criminal law codification. Based on this it can be affirmed that the purpose of the principle of legality are to strengthen the rule of law, creating justice and fairness to the accused, effective deterrent function of criminal sanctions, tercegahnya abuse of power, and pharmaceutics application of the principle of rule of law. Indonesian legal system, particularly the principle of legality put in Article 1 (1) of the Criminal Code. Later in the pair, this principle requires that judges dependent on legislation. This confirms that the criminal justice process or the criminal procedure is executed according to the event, process, or procedure that has been regulated by law, namely Article 3 of the Criminal Procedure Code.

The formulation of the principle of legality of von Feuerbach in Latin was presented in connection with the theory vom psychologischen zwang, namely that suggested that in determining the acts that are prohibited by laws not only about the kind of action that is written clearly, but also about the kind of punishment imposed. In this way, then every person who would do the deed dilaran first have to know what the punishment to be imposed to him the next time the act was committed. Thus, in their heart, and there is an awareness or pressure to not do it. And if it ends that action remain to be done, then if the offender was sentenced for criminal acts, can be considered the perpetrator has mneyetujuinya. Thus, the establishment of the criminal von Feuerbach is classified absolute conviction. Similarly, the theory of retaliation (Retribution).

\subsection{The principle of legality and Retroactive the Indonesian Penal Code}

In criminal law, known as the principle of legality, the principle which determines that no prohibited and punishable by otherwise determined in advance in the legislation. In Latin, known as Nullum delictum nulla poena sine praevia lege poenalli which means more or less is no offense, no criminal without rules beforehand This principle is today more often aligned with the principle of non-retroactivity, or principle that legislation should not be retroactive. Quite simply, this principle states that there shall be punished if there are no rules.

Article 1 (1) of the Criminal Code "There's nothing like a criminal act can be in, except for the strength of the criminal rules in the legislation that has existed before the act was committed"

In Article 1 of the Code of Penal tells us that:

- An act can be imprisoned if included penal provisions under law. Therefore sentencing by the unwritten law is not possible;

- The criminal provisions must first exist than the act, in other words, the criminal provisions should have come into force when the act was committed. Therefore, the provision does not apply retroactively (principle of non-retroactivity), both on the statute can be imprisoned or sanctions.

- Article 1 (2) of the Criminal Code makes an exception to the provision is not retroactive to the interests of the accused. So, all favorable to the accused, then the implementation of the new penal code (although retroactive) can be implemented. 
In accordance with the spirit of article 1 of the Criminal Code, is required also that the provisions of the law must be formulated as carefully as possible. This is called the principle of lex certa. The law should limit the government's sharp and clear authority to the people (lex certa: laws can be trusted). A basic understanding of article 1 of the Criminal Code also deals with the soul of Article 3 of the Criminal Code: the criminal law must be realized with adequate procedures and legal guarantees.

Satochid Kertanegara in Criminal Law books (collection of lectures) states that the presence of Article 1 (1) of the Criminal Code of the above, the Penal Code can not be applied retroactively. This means that:

- Penal Code can not be applied retroactively, this is the first principle. The ratio is that the Criminal Code must be based on written rules (principle of nonretroactivity);

- Penal Code must be based on written rules.

So criminal law should not be rooted in customary law, or the unwritten law. Another with civil law where customary law is still one of the sources of law. This is contrary to the opinion of Prof. Moeljatno stating that the traditional criminal law still applies even if only for certain people and temporary. Basically is Article 14 paragraph 2 of the Provisional Constitution.

So by reviewing the terms as set out in Article 1 (1) where the pressure is placed on the word of "previous", This indicates that the criminal law can not be retroactive. But this principle is not an absolute principle. As previously stated in the fruit of the ideas of Prof. Moeljatno above, in line with it, Prof. Satochid mammal also said that the principle of non-retroactivity of the present, there are exceptions in Article 1 (2) which reads: If, after the deed is done there is a change in the law, used the lightest rule for the defendant. Of these rules, it can be concluded that this paragraph allows treating the Criminal Code retroactively, in general, to treat retroactive legislation (principle of retroactivity), throughout, the new law is more favorable to the accused / suspect. To understand the rules of paragraph (2) is, first of all have to understand what is meant by a change in legislation. Such amendment is a change that occurs after someone does something which is prohibited, and punishable by the law, and if the law of this new more profitable than the laws of time then legislation recently to be treated to himself. So in short, the Criminal Code should be treated retroactively if:

- Do changes in legislation;

- This change occurred after a person committing prohibited and punishable by the law, but before sentenced to such actions;

- New legislation especially favorable for the suspect, rather than the old legislation.

Applicability of the principle of legality, as described above provide protection to the nature of the criminal law: the criminal law to protect the people against the exercise of power without limits of government. This is called the function of protecting from criminal laws. Besides the function of protecting the criminal laws also have the instrumental function that is within the limits prescribed by law, the exercise of power by the government explicitly allowed. The principle of legality has to do with the instrumental function of the criminal laws.

Usually the principle of legality is in question contains three terms, namely: 
- No prohibited and punishable by if it first has not been stated in a rule legislation. The first sense mentioned above, that there should be rules shrimp legislation so legal rules written beforehand, clearly in Article 1 (1) of the Criminal Code, where the Dutch text stated: "wettelijke strafbepaling", Namely the criminal rules in legislation. But with this provision, the consequences are criminal acts under customary law and can not be convicted, because there are not determined by the rules are written.

- To determine the existence of a criminal act can not be used analogy / kiyas. The principle that in determining whether or not a criminal act can not be used analogy (Qiyas) generally still used by most countries. In Indonesia and in the Netherlands in general is still recognized this principle, although there are also some experts can not agree to this, for example Taverne, Pompe and Jonkers. Prof. Scholter reject the difference between analogy and extensive interpretation, ostensibly allowed. In his opinion, both in terms of extensive interpretation, as well as in the analogy is essentially the same, namely to try to find the norms of a higher (more general or abstract) than the existing norms. The application of the law by analogy this means the introduction of a provision on a case that is not included in it. The implementation is based on the analogy of the criminal provisions of the events are no doubt worth diidana, but does not include any criminal laws had ever done.

- Rules of criminal law is not retroactive. There's nothing like an act can be imprisoned unless there are penal provisions under the laws that have been there before, semikian article 1, paragraph (1) of the Criminal Code. Paragraph (2) of the article provides an exception as we have discussed above. This rule applies to the whole proceedings. In other words, if the time between the decision of first instance and appeal, or the appeal in cassation change the law for the benefit of the defendant, the District Court, High Court and the Supreme Court should apply Article 1 (2) of the Criminal Code. Remember, the prohibition applies only to the receding power of criminal provisions. Not to regulatory jurisdiction with authority berhubngan eg forming other national laws. However Sahetapy added another four aspects namely:

- Can not be convicted solely based on habit. Punishment should also be based on law, not allowed by habit. So the violation of customs rules by itself has not resulted in criminal acts. Nevertheless, it does not mean that the rules of customs rules played no role in criminal law. Sometimes criminal legislation implicitly or explicitly refer to it. The appointment is implicitly contained in the blanket habit to norm as in article 282 of the Criminal Code, and some offense omission which did not do may be liable. Appointment explicitly into the habit of Article 8 Wet Oorlogsstrafrecht 1950 (Law on the Criminal Law of War in the Netherlands) which threatens serious crimes against the violation of laws and customs of war. These provisions are all in violation of the principle of lex-chert.

- There should be no less clear formulation of offenses (lex certa requirement).

Lex certa requirement means that the law must be sufficiently clear, so that: It is a handbook for citizens in choosing their behavior, danUntuk provide certainty to the authorities concerning the delimitation of authority limits. But it is impossible to 
formulate all behavior should be convicted carefully in the legislation. The terms are set by law for public behavior, is also determined based on the prevailing custom there. Nevertheless, people are entitled to ask whether lawmakers with Article 8 Wet Oorlogsrecht not too easy to accomplish its task.

- There is no other punishment except as provided by law. The law determines the criminal-sentence imposed, according to the wording of Article 89 paragraph (2) Dutch Constitution. By law here is the law in the formal sense. Legislators lower can make criminal laws to the extent permitted by the law makers formal. But it must not create any other crime than had been arranged and specified by law in the formal sense. Judges were not allowed to convict other than those specified by law. However, Article 14a of the Criminal Code authorizes a judge to set a special condition to conditional punishment in the form of certain obligations that must be met by the convict, but it is no limitations.

- Only criminal prosecution in the manner specified by statute. Criminal prosecution is the entire criminal proceedings, from the investigation to the implementation of the criminal (compare Article 1 paragraph 7 KUHAP: prosecution is an act of the public prosecutor to delegate the criminal case to the district court that is competent in this case in the manner set forth in this law to demand that examined and decided upon by the judge in court. rules of criminal procedure is thus the same in all countries. the ban makes the rules of criminal procedure apply to legislators lower, not for legislators in the formal sense.

\subsection{Retroactive principle of legality and the Criminal Code of Thailand}

Provisions on the principle of legality in the Criminal Code of Thailand under Article 2 of the General Regulations Book I, which states as follows:

"A person shall be Criminally punished only when the act done by him is provided ri be an offense and the punishment is defined by the law in force at the time of the doing such act, and the punishment to be inflicted upon the Offender shall be that provided by the law.

If, According to the law Provided afterwards, such act is no more an offense, the person doing such act shall be relieved from being an Offender, and if there is a final judgment inflicting the punishment, such person be deemend as not having ever been convicted by the judgment for committing such offense. If, however, he is still undergoing the punishment, the punishment shall forthwith terminate."

Which mean:

"A person will only be convicted if the deed done by him designated as a crime and criminal formulated by the Act in force at the time they were committed, and the punishment imposed on the offender is a crime as stipulated by the law.

If according to the Act stipulated later, the act was no longer a criminal offense, the person who violated the act would be released as perpetrators / pelanggat, and if there is a verdict sentencing the final (finalized), that person shall be deemed to have not been sentenced for the act, however, when he was a sentence that will be terminated immediately." 
In Article 2 (1) contains a principle of lex temporis delicti. Article 2 (2) (Retroactive) regulates the amendments states that the acts governed by the old Law is no longer a crime according to the new law. In such case there are two possibilities:

- If no decision is based on the old law, the defendant will be released as a violator for his actions according to the new Law is no longer a criminal offense.

- If existing sentencing verdict and binding by the old Law

- If the criminal has not been served, the defendant is considered as never convicted

- If the accused is undergoing the most criminal penal rest will be terminated.

In This according to a new law, acts that governed the old law is still seen as a criminal act then, in this regard Article 3 of the Criminal Code of Thailand asserts that the law more favorable that it will impose the offender. Except if the matter has got a permanent legal berkuatan decisions based on old laws.

\section{Conclusion}

Basically, one of the things you want to achieve the principle of legality is to strengthen the rule of law, creating justice and fairness to the accused, streamline the functions of deterrence to criminal sanctions, prevent abuse, and strengthen the rule of law. ${ }^{6}$ This principle is very effective in protecting people from abuses of power, but it is less effective for law enforcement to respond to the rapid development of crime.

In the Indonesian Penal Code, the principle of legality contained in Article 1 (1) where the pressure is placed on the word of "previous", This indicates that the criminal law can not be retroactive. However, in Article 1 (2) which reads: If, after the deed is done there is a change in the law, used the lightest rule for the defendant. In this verse allows treating the Criminal Code retroactively, in general, to treat retroactive legislation (principle of retroactivity), throughout, the new law is more favorable to the accused / suspect. The changes that occurred after someone does something which is prohibited, and punishable by the law, and if the new law is more favorable than the old law the new legislation it should be treated to himself.

Similarly, the principle of legality contained in the Criminal Code of Thailand. There is no significant difference regarding the conceptual principle of legality in the Criminal Code of the country. In the Criminal Code of Thailand, the principle of legality provided for in Article 2 paragraph (1) and (2) yangmana onArticle 2 (1) also describes the principle of lex temporis delicti which means that the applicable law is the law existing at the time the offense occurred, this principle is also called the principle of nonretroactivity. Which notabennya together with Article 1 (1) of the Indonesian Penal Code. Whereas in Article 2 paragraph (2) of the Criminal Code of Thailand explained on the entry into force of the retroactive principle set their amendments stating that the act which is governed by the old Law is no longer a crime according to the new law. It also has the same meaning as in Article 1 (2) of the Criminal Code of Indonesia.

\footnotetext{
${ }^{6}$ Muladi 2002.
} 


\section{Reference}

[1] Arief, Barda Nawawi, 2010, Perbandingan Hukum Pidana, PT RajaGrafindo Persada, Jakarta.

[2] Bambang Poernomo, 1994, Asas-asas Hukum Pidana, Ghalia Indonesia, Jakarta.

[3] Barda Nawawi Arief, 2003, Kapita Selekta Hukum Pidana, Citra Aditya Bakti, Bandung.

[4] P.A.F. Lamintang, 1997, Dasar-dasar Hukum Pidana, Citra Aditya Bakti, Bandung.

[5] Romli Atmasasmita, 2002, Pengadilan Hak Asasi Manusia dan Penegakannya di Indonesia, BPHN, Jakarta.

[6] Moeljatno, 2002, Asas - Asas Hukum Pidana, Rineka Cipta, Jakarta.

[7] Moh Mahfud MD, Cetakan Kedua 2010, Sifat Melawan Hukum Dalam Tindak Pidana Korupsi, Indonesia Lawyer Club, Surabaya. 